\section{Toward a New}

Paradigm in Open Economy Modeling: Where Do We Stand?

\author{
Lucio Sarno
}

( $\mathrm{n}$ the last few decades, there have been a num ber of important developments, both theoretical and empirical, in open economy macroeconomics and exchange rate economics (see, for example, Sarno and Taylor, 2001a, b). Also, the increasing availability of high-quality macroeconomic and financial data has stimulated a large amount of empirical work. While our understanding of exchange rates has improved as a result, many challenges and questions remain. This paper selectively surveys the recent literature on "new" open economy macroeconomics. This literature, stimulated by the work of Obstfeld and Rogoff (hereafter OR) (1995), reflects the attempt by researchers to formalize exchange rate determination in the context of dynamic general equilibrium models with explicit microfoundations, nominal rigidities, and imperfect competition. ${ }^{1}$

The main objective of this research program is to develop a new workhorse model for open economy macroeconomic analysis. Relative to the still ubiquitous Mundell-Fleming-Dornbusch (MFD) model (Mundell, 1962, 1963; Fleming, 1962; Dornbusch, 1976), new open economy models offer a higher standard of analytical rigor coming from fully specified microfoundations; they offer the ability to perform welfare analysis and rigorously discuss policy evaluation in the context of a framework that allows for market imperfections and nominal rigidities. On the other hand, the main virtue of the MFD model is its simpler analytical structure, which makes it easy to discuss in

\footnotetext{
Lucio Sarno is a reader in economics and finance at the Warwick Business School, University of Warwick, and a research affiliate of the Centre for Economic Policy Research, London. This paper was written in part while the author was a visiting scholar at the Federal Reserve Bank of St. Louis. The author thanks the United Kingdom Economic and Social Research Council (ESRC) for providing financial support (grant No. L138251044) and Gaetano Antinolfi, James Bullard, Giancarlo Corsetti, Brian Doyle, Fabio Ghironi, Peter Ireland, Marcus Miller, Chris Neely, Michael Pakko, Neil Rankin, Mark Taylor, and Dan Thornton for constructive comments. Paige Skiba provided research assistance. The views expressed are those of the author and should not be interpreted as reflecting those of any institution.
}

policy circles. Because the predictions of new open economy models are sensitive to the particular specification of the microfoundations, policy evaluation and welfare analysis depend on the specification of preferences and nominal rigidities. In turn, this generates a need for the profession to agree on the "correct" or at least "preferable" specification of the microfoundations.

The present paper reviews the key contributions in new open economy macroeconomics in the last five to six years, also assessing how the intellectual debate stimulated by OR has led to models that reflect reality more satisfactorily over time. The paper also discusses some of the most controversial issues that currently still prevent any of the models in this area to emerge as a new paradigm for open economy modeling and describes the directions taken by the latest literature.

The remainder of the paper is set out as follows. The first section provides a review of the seminal paper in this literature, proposing the socalled redux model, while the second section covers a number of variants and generalizations of the redux model that permit allowance for alternative nominal rigidities, pricing to market, alternative preference specifications, and alternative financial markets structures. I then discuss some stochastic extensions of these models, focusing on their implications for the relationship between uncertainty and exchange rates in the third section. Some new directions taken by the latest literature on stochastic open economy modeling are described in the fourth section. A final section presents some concluding remarks.

\section{THE REDUX MODEL}

\section{The Baseline Model}

OR (1995) is the study often considered as having initiated the literature on new open economy macroeconomics (see, for example, Lane, 1999, and Corsetti and Pesenti, 2001). However, a precursor of the OR (1995) model that deserves to be noted here is the model proposed by Svensson

\footnotetext{
1 An early draft of this paper covered some of the models discussed below in a more technical fashion. The preliminary technical version is available from the author upon request (Sarno, 2000). Walsh (1998) also provides an excellent treatment of the redux model, especially focusing on monetary issues. See also the comprehensive textbook treatment of the early new open economy literature by OR (1996) and its selective coverage by Lane (1999). For a treatment of the role of imperfect competition in macroeconomic models, see the survey by Dixon and Rankin (1994).
} 
and van Wijnbergen (1989). They present a stochastic, two-country, neoclassical rational-expectations model with sticky prices that are optimally set by monopolistically competitive firms, where possible excess capacity is allowed for to examine international spillover effects of monetary disturbances on output. In contrast to the prediction of the MFD model that a monetary expansion at home leads to a recession abroad, the paper suggests that spillover effects of monetary policy may be either positive or negative, depending on the relative size of the intertemporal and intratemporal elasticities of substitution in consumption. It is also fair to say that the need for rigorous microfoundations in open economy models is not novel in new open economy macroeconomics and has been emphasized by several papers prior to OR (1995); notable examples are Lucas (1982), Stockman (1980, 1987), and Backus, Kehoe, and Kydland (1992, 1994, 1995), among others.

The baseline model proposed by OR (1995) is a two-country, dynamic general equilibrium model with microfoundations that allows for nominal price rigidities, imperfect competition, and a continuum of agents who both produce and consume. Each agent produces a single differentiated good. All agents have identical preferences, characterized by an intertemporal utility function that depends positively on consumption and real money balances but negatively on work effort; effort is positively related to output. The exchange rate is defined as the domestic price of the foreign currency. The two countries are called Home and Foreign, respectively.

Because the model assumes no impediments to international trade, the law of one price (LOOP) holds for each individual good and purchasing power parity (PPP) holds for the internationally identical aggregate consumption basket. PPP is the proposition that national price levels should be equal when expressed in a common currency; the LOOP is the same proposition applied to individual goods rather than a consumption basket. Since the real exchange rate is the nominal exchange rate adjusted for relative national price levels, variations in the real exchange rate represent deviations from PPP. Hence, the LOOP and continuous PPP imply a constant real exchange rate, while long-run PPP (where temporary deviations from PPP are allowed for) implies mean reversion in the real exchange rate.

OR also assume that both countries can borrow and lend in an integrated world capital mar- ket. The only internationally traded asset is a riskless real bond, denominated in the consumption good. Agents maximize lifetime utility subject to their budget constraints (identical for domestic and foreign agents). Utility maximization then implies three clearly interpretable conditions. The first is the standard Euler equation, which implies a flat time path of consumption over time. The second condition is the money market equilibrium condition that equates the marginal rate of substitution of consumption for the services of real money balances to the consumption opportunity cost of holding real money balances (the nominal interest rate); the representative agent directly benefits from holding money in the utility function but loses the interest rate on the riskless bond as well as the opportunity to eliminate the cost of inflation. (Note that money demand depends on consumption rather than income in this model.) The third condition requires that the marginal utility of the higher revenue earned from producing one extra unit of output equals the marginal disutility of the needed effort, and so can be interpreted as a labor-leisure trade-off equation.

In the special case when net foreign assets are zero and government spending levels are equal across countries, OR solve the model for income and real money balances. Because this model is based on a market structure with imperfect competition where each agent has some degree of market power arising from product differentiation, the solutions of the model imply that steadystate output is suboptimally low. As the elasticity of demand (say $\theta$ ) increases, the various goods become closer substitutes and, consequently, the monopoly power decreases. As $\theta$ approaches infinity, output increases, tending to the level corresponding to a perfectly competitive market.

The main focus of OR (1995) is the impact of a monetary shock on real money balances and output. Under perfectly flexible prices, a permanent shock produces no dynamics and the world economy remains in steady state (prices increase by the same proportion as the money supply). That is, an increase in the money supply has no real effects and cannot remedy the suboptimal output level. Money is neutral. ${ }^{2}$

\footnotetext{
2 Note that in the redux model and in a number of subsequent papers, monetary shocks are discussed without a formalization of the reaction functions of the monetary authorities. However, some recent studies have formally investigated reaction functions in new open economy macroeconomic models; see, for example, Ghironi and Rebucci (2000) and the references therein.
} 
With prices displaying stickiness in the short run, however, monetary policy may have real effects. If the money supply increases, because prices are fixed, the nominal interest rate decreases and hence the exchange rate depreciates. This is because, due to arbitrage in the foreign exchange market, uncovered interest parity holds. Foreign goods become more expensive relative to domestic goods, generating a temporary increase in the demand for domestic goods and inducing an increase in output. Consequently, monetary shocks generate real effects on the economy. But how can one ensure that producers are willing to increase output? If prices are fixed, output is determined by demand. Because a monopolist always prices above the marginal cost, it is profitable to meet unexpected demand at the fixed price. Noting that in this model the exchange rate rises less than the money supply, currency depreciation shifts world demand toward domestic goods, which causes a short-run rise in domestic income. Home residents consume some of the extra income, but, because they want to smooth consumption over time, they save part of it. Therefore, although in the long run the current account is balanced, in the short run Home runs a current account surplus. With higher long-run wealth, Home agents shift from work to leisure reducing Home output. Nevertheless, because Home agents' real income and consumption rise in the long run, the exchange rate does not necessarily depreciate. ${ }^{3}$

Unlike the scenario in a Dornbusch-type model, the redux model does not yield exchange rate overshooting. The exchange rate effect is smaller the larger the elasticity of substitution, $\theta$; as $\theta$ approaches infinity, Home and Foreign goods become closer substitutes, producing larger shifts in demand with the exchange rate changing only slightly.

Finally, a monetary expansion leads to a firstorder welfare improvement. ${ }^{4}$ Because the price exceeds the marginal cost in a monopolistic equilibrium, global output is inefficiently low. An unanticipated money shock raises aggregate demand stimulating production and mitigating the distortion.

Summing up, in the redux model, monetary shocks can generate persistent real effects, affecting consumption and output levels and the exchange rate, although both the LOOP and PPP hold. Welfare rises by equal amounts at home and abroad after a positive monetary shock, and pro- duction is moved closer to its efficient (perfectly competitive market) level. Adjustment to the steady state occurs within one period, but money supply shocks can have real effects lasting beyond the time frame of the nominal rigidities because of the induced short-run wealth accumulation via the current account. Money is not neutral, even in the long run.

\section{A Small Open Economy Version of the Baseline Model}

The baseline redux model and most of the subsequent literature on new open economy macroeconomics are based on a two-country framework, which allows an explicit analysis of international transmission channels and the endogenous determination of interest rates and asset prices. Nevertheless, similar, simpler models may be constructed under the assumption of a small open economy rather than a two-country framework. In the small open economy version it is also easier to allow a distinction between tradable and nontradable goods in the analysis. OR (1995) provide such an example in their Appendix. In this model, monopolistic competition characterizes the nontradable goods sector. The tradable goods sector is characterized by a single homoge nous tradable good that sells for the same price all over the world, perfect competition, and flexible prices. The representative agent in the small open economy, called Home, has an endowment of the tradable good in constant quantity in each period and monopoly power over the production of one of the nontradable goods.

In this setup, a permanent monetary shock does not generate a current account imbalance. Because output of tradable goods is fixed, current account behavior is determined by the time path for tradables consumption, which, under logseparable preferences and a discount rate equal to

\footnotetext{
3 Again, note that in this model money demand depends on consumption rather than income. Thus, an increase in consumption due to an increase in the nominal money supply raises money demand by the same proportion.

4 In order to produce more, Home agents have to work harder. The effects from reallocating consumption-production and leisure over time are second-order, and the excess demand that leads to an increase in production outweighs these effects. Of course, welfare results depend upon the welfare function assumed. In the present context, for example, it is important to note that inflation costs (obviously generated by an expansionary monetary policy) are not modeled explicitly.
} 
the world interest rate, implies a perfectly flat optimal time path for consumption. Hence, the current account remains in balance. Unlike the scenario in the baseline redux model, however, exchange rate overshooting may occur in this model. Since the monetary shock does not produce a current account imbalance, money is neutral in the long run and the nominal exchange rate rises proportionately to the money stock. Because the consumption elasticity of money demand is less than unity (by assumption), the nominal exchange rate overshoots its long-run level. ${ }^{5}$

Lane (1997) uses this small open economy model to examine discretionary monetary policy and the impact of openness (measured by the relative size of the tradables sector) on the equilibrium inflation rate. A more open economy (with a large tradables sector) gains less from "surprise" inflation because the output gain from a monetary expansion is exclusively obtained in the nontradables sector and is relatively low. Since the equilibrium inflation rate under discretion is positively related to the gains from "surprise" inflation (Barro and Gordon, 1983), the model predicts that more open economies have lower equilibrium inflation rates (see also Kollmann, 1997; Velasco, 1997).

Lane (2001) further extends this model by considering an alternative specification of the utility function under which monetary shocks generate current account imbalances. The sign of the current account response is ambiguous, however; in fact, it depends on the interplay between the intertemporal elasticity of substitution, $\sigma$, and the intratemporal elasticity of substitution, $\theta$. $\sigma$ governs the willingness to substitute consumption across periods, while $\theta$ governs the degree of substitutability between traded and nontraded consumption. If $\sigma<\theta$, a positive monetary shock generates a current account surplus; however, a current account deficit occurs if $\sigma>\theta$, whereas the current account remains in balance if $\sigma=\theta$. Hence, this model clearly illustrates how the results stemming from this class of models are sensitive to the specification of the microfoundations.

The implications of small open economy models of this class seem plausible. While the relevant literature (and consequently the rest of this survey) largely uses a two-country global economy framework, I think it might also be worthwhile to pursue research based on the small open economy assumption. Indeed, the small open economy assumption is plausible for most coun- tries, except the United States. Furthermore, testing the empirical implications of the small open economy models discussed in this section represents a new line of research for applied economists.

\section{RETHINKING THE REDUX MODEL}

\section{Nominal Rigidities}

As mentioned earlier, subsequent work has modified many of the assumptions of the redux model. In this section, I discuss modifications based on the specification of nominal rigidities. The open economy literature surveyed here provides some novel thoughts in this context and might generate evidence for choosing among alternative specifications of stickiness in macroeconomic models. Whether the extension from closed to open economy models does help to achieve consensus on the specification of nominal rigidities remains to be seen (see, for example, the arguments presented by OR, 2000a, discussed below).

With respect to nominal rigidities, the redux model assumes that prices are set one period in advance, which implies that the adjustment to equilibrium is completed after one period. As Corsetti and Pesenti (2001) emphasize, however, if price stickiness is motivated by fixed menu costs, firms have an incentive to adjust prices immediately after a shock if the shock is large enough to violate their participation cost by raising the marginal cost above the price. Hence, the redux analysis may be seen as plausible only within the relevant range of shocks.

Hau (2000) generalizes the redux model in three ways to investigate the role of factor price (wage) rigidities and nontradables for the international transmission mechanism. First, following Blanchard and Kiyotaki (1987), the model allows for factor markets and for nominal rigidities originating from sticky factor prices (wages). Second, Hau assumes flexible price setting in local currency and does not assume international goods arbitrage. While the LOOP still holds because of optimal monopolistic price setting, nontradables in the consumer price index produce deviations from PPP. Third, unlike the scenario in the redux analysis, Hau also allows for nontradable goods. The main result of the paper is that factor price rigidities have similar implications to rigid domes-

\footnotetext{
5 Indeed, this is exactly the same overshooting condition derived in
} the Dornbusch (1976) model. 
tic producer prices. In some sense, the results of the redux analysis are confirmed in the context of a market structure with factor price rigidities. However, nontradables modify the transmission mechanism in important ways. A larger nontradables share implies that exchange rate movements are magnified, since the money market equilibrium relies on a short-run price adjustment carried out by fewer tradables. This effect is interesting since it may help explain the observed high volatility of the nominal exchange rate relative to price volatility.

Within the framework of price level rigidities, however, a more sophisticated way of capturing price stickiness is through staggered price setting that allows smooth, rather than discrete, aggregate price level adjustment. Staggering price models of the type developed by, among others, Taylor (1980) and Calvo (1983) are classic examples. Kollmann (1997) calibrates a dynamic open economy model with both sticky prices and sticky wages and then explores the behavior of exchange rates and prices in response to monetary shocks with predetermined price and wage setting and Calvo-type nominal rigidities. His results suggest that Calvo-type nominal rigidities match very well the observed high correlation between nominal and real exchange rates and the smooth adjustment in the price level, but they match less well correlations between output and several other macroeconomic variables.

Chari, Kehoe, and McGrattan (CKM) (1998, 2000) link sticky price models to the behavior of the real exchange rate in the context of a new open economy macroeconomic model. They start by noting that the data show large and persistent deviations of real exchange rates from PPP that appear to be driven primarily by deviations from the LOOP for tradable goods. That is, real and nominal exchange rates are about six times more volatile than relative price levels and both are highly persistent, with first-order serial correlations of about 0.85 and 0.83 , respectively, at annual frequency. CKM then develop a sticky price model with pricediscriminating monopolists that produces deviations from the LOOP for tradable goods. However, their benchmark model, which has prices set for one quarter at a time and a unit consumption elasticity of money demand, does not come close to reproducing the serial correlation properties of real and nominal exchange rates noted above. A model in which producers set prices for six quarters at a time and with a consumption elasticity of money demand of 0.27 does much better in generating persistent and volatile real and nominal exchange rates. The serial correlations of real and nominal exchange rates are 0.65 and 0.66 , respectively, and exchange rates are about three times more volatile than relative price levels.

In a closely related paper, Jeanne (1998) attempts to assess whether money can generate persistent economic fluctuations in a dynamic general equilibrium model of the business cycle. Jeanne shows that a small nominal friction in the goods market can make the response of output to monetary shocks large and persistent if it is amplified by real-wage rigidity in the labor market. He also argues that, for plausible levels of real-wage rigidity, a small degree of nominal stickiness may be sufficient for money to produce economic fluctuations as persistent as those observed in the data. ${ }^{6}$

OR (2000a), discussed in detail later in this paper, develop a stochastic new open economy macroeconomic model based on sticky nominal wages, monopolistic competition, and exporterscurrency pricing. Solving explicitly the wage-setting problem under uncertainty allows the analysis of the welfare implications of alternative monetary regimes and their impact on expected output and terms of trade. To motivate their model, OR show that observed correlations between terms of trade and exchange rates appear to be more consistent with their assumptions about nominal rigidities than with the alternative specification based on local-currency pricing.

I now turn to a discussion of the reformulations of the redux model based on the introduction of pricing to market.

\section{Pricing to Market}

While the redux model assumes that the LOOP holds for all tradable goods, a number of researchers have questioned the model on the ground that deviations from the LOOP across international borders appear to be larger than can be explained by geographical distance or transport costs (see, for example, Engel, 1993, and Engel and Rogers, 1996). Some authors have therefore extended the redux model by combining international segmentation with imperfectly competitive firms and local-currency pricing (essentially pricing to market or PTM). Krugman (1987) used the term PTM to characterize price discrimination for

6 See also Andersen (1998), Benigno (1999), and Bergin and Feenstra (1999, 2000). 
certain types of goods (such as automobiles and many types of electronics) where international arbitrage is difficult or perhaps impossible. This may be due, for example, to differing national standards (for example, 100-volt light bulbs are not used in Europe and left-hand-side-drive cars are not popular in the United Kingdom, Australia, or Japan). Further, monopolistic firms may be able to limit or prevent international goods arbitrage by refusing to provide warranty service in one country for goods purchased in another. To the extent that prices cannot be arbitraged, producers can discriminate across different international markets.

Studies allowing for PTM typically find that PTM may play a central role in exchange rate determination and in international macroeconomic fluctuations. This happens because PTM acts to limit the pass-through from exchange rate movements to prices, reducing the "expenditure switching" role of exchange rate changes and potentially generating greater exchange rate variability than would be obtained in models without PTM. Also, nominal price stickiness, in conjunction with PTM, magnifies the response of the exchange rate to macroeconomic fundamentals shocks. Further, by generating deviations from PPP, PTM models also tend to reduce the comovement in consumption across countries while increasing the comovement of output, fitting some well-known empirical regularities (see Backus, Kehoe, and Kydland, 1992). Finally, the introduction of PTM has important welfare implications for the international transmission of monetary policy shocks, as discussed below.

Betts and Devereux (2000b), for example, characterize PTM by assuming that prices of many goods are set in the local currency of the buyer and do not adjust at high frequency. Consequently, real exchange rates move with nominal exchange rates at high frequency. These assumptions also imply that price/cost markups fluctuate endogenously in response to exchange rate movements rather than nominal prices (see also Knetter, 1993, on this point). In the Betts-Devereux framework, traded goods are characterized by a significant degree of national market segmentation and trade is carried out only by firms. Households cannot arbitrage away price differences across countries, and firms engage in short-term nominal price setting. Therefore, prices are sticky in terms of the local currency. ${ }^{7}$

The Betts-Devereux model is based on an economy with differentiated products and assumes that firms can price-discriminate across countries. With a high degree of PTM (that is, when a large fraction of firms engages in PTM), a depreciation of the exchange rate has little effect on the relative price of imported goods faced by domestic consumers. This weakens the allocative effects of exchange rate changes relative to a situation where prices are set in the seller's currency; in the latter case, pass-through of exchange rates to prices is immediate. Hence, PTM reduces the expenditure switching effects of exchange rate depreciation, which generally implies a shift of world demand toward the exports of the country whose currency is depreciating. Because domestic prices show little response to exchange rate depreciation under PTM, the response of the equilibrium exchange rate may be substantially magnified and, consistent with well-known observed empirical regularities, exchange rates may vary more than relative prices.

PTM also has implications for the international transmission of macroeconomic shocks. In the absence of PTM, for example, monetary disturbances tend to generate large positive comovements of consumption across countries but large negative comovements of output. However, PTM reverses the ordering: the deviations from PPP induced by PTM make consumption comovements fall. At the same time, the elimination of expenditure switching effects of the exchange rate enhances comovements of output across countries.

In terms of welfare, recall that the framework based on the LOOP and PPP generally suggests that an unanticipated monetary expansion raises welfare of all agents at home and abroad. With PTM, however, a domestic monetary expansion raises home welfare but reduces foreign welfare and monetary policy is a "beggar-thy-neighbor" instrument. Therefore, the PTM framework, unlike the framework based on the LOOP and PPP, provides a case for international monetary policy coordination.

Overall, the PTM framework suggests that goods market segmentation might help explain international quantity and price fluctuations and may have important implications for the international transmission of economic shocks, policy, and welfare.

\footnotetext{
7 The model of Betts and Devereux (2000b) is used as a representative of this class of PTM models in this section. Other examples of models adopting PTM are Betts and Devereux (1996, 1997, 1999, 2000a); CKM (1998, 2000); and Bergin and Feenstra (1999, 2000).
} 


\section{The Indeterminacy of the Steady State}

In the framework proposed by OR (1995), the current account plays a crucial role in the transmission of shocks. However, the steady state is indeterminate and both the consumption differential between countries and an economy's net foreign assets are nonstationary. After a monetary shock, the economy will move to a different steady state until a new shock occurs. When the model is loglinearized to obtain closed-form solutions of the endogenous variables, one is approximating the dynamics of the model around a moving steady state. This makes the conclusions implied by the model questionable. In particular, the reliability of the log-linear approximations is low because variables wander away from the initial steady state.

Many subsequent variants of the redux model de-emphasize the role of net foreign assets accumulation as a channel of macroeconomic interdependence between countries. This is done by assuming that (i) the elasticity of substitution between domestic and foreign goods is unity or (ii) financial markets are complete. Both of these assumptions imply that the current account does not react to shocks (see, for example, Corsetti and Pesenti, 2001, and OR, 2000a). ${ }^{8}$ While this framework achieves the desired result of determinacy of the steady state, it requires strong assumptions(i) or (ii) above-to shut off the current account, which is unrealistic. In a sense these solutions circumvent the problem of indeterminacy, but they do not solve it.

Ghironi (2000a) provides an extensive discussion of the indeterminacy and nonstationarity problems in the redux model. Ghironi also provides a tractable two-country model of macroeconomic interdependence that does not rely on either of the above assumptions in that the elasticity of substitution between domestic and foreign goods can be different from unity and that financial markets are incomplete, consistent with reality. Using an overlapping generations structure, Ghironi shows how there exists a steady state, endogenously determined, to which the world economy reverts following temporary shocks. Accumulation of net foreign assets plays a role in the transmission of shocks to productivity. Finally, Ghironi also shows that shutting off the current account may lead to large errors in welfare comparisons, which calls for rethinking of several results in this literature.

The issue of indeterminacy of the steady state deserves further attention from researchers in this area.

\section{Preferences}

While the explicit treatment of microfoundations is a key advantage of new open economy macroeconomic models relative to the MFD model, the implications of such models depend on the specification of preferences. One convenient assumption in the redux model is the symmetry with which home and foreign goods enter preferences in the constant-elasticity-of-substitution (CES) utility function. Corsetti and Pesenti (2001) extend the redux model to investigate the effects of a limited degree of substitution between home and foreign goods. In their baseline model, the LOOP still holds and technology is described by a Cobb-Douglas production function, with a unit elasticity of substitution between home and foreign goods and constant income shares for home and foreign agents. The model illustrates that the welfare effects of expansionary monetary and fiscal policies are related to internal and external sources of economic distortion, namely, monopolistic supply in production and monopoly power of a country. For example, an unanticipated exchange rate depreciation can be "beggar-thyself" rather than "beggarthy-neighbor" since gains in domestic output are offset by losses in consumers' purchasing power and a deterioration in terms of trade. Also, openness is not inconsequential: smaller and more open economies are more prone to inflationary consequences. Fiscal shocks, however, are generally "beggar-thy-neighbor" in the long run, but they raise domestic demand in the short run for given terms of trade. These results provide a role for international policy coordination, which is not the case in the redux model. ${ }^{9,10}$

An important assumption in the redux model is that consumption and leisure are separable. This

8 This is a problem often encountered in the international real business cycles literature. Note, however, that the role of current account dynamics in generating persistent effects of transitory shocks has often been found to be quantitatively unimportant in this literature. See the discussion on this point by Baxter and Crucini (1995) and Kollmann (1996).

9 Recall that the redux model has the unrealistic implication that the optimal monetary surprise is infinite, which is of course not the case in the Corsetti-Pesenti model.

10 Devereux (1999), Doyle (2000), Tille (1998a, b), Betts and Devereux (2000a), and Benigno (2001), among others, represent attempts to model explicitly international policy coordination in variants of the Corsetti-Pesenti model. See also OR (2000b). 
assumption is not compatible, however, with a balanced growth path if trend technical progress is confined to the market sector. As a country becomes richer, labor supply gradually declines, converging to a situation in which labor supply is zero, unless the intertemporal elasticity of substitution is unity. CKM (1998), for example, employ a preference specification with nonseparable consumption and leisure (which is fairly standard, for example, in the real business cycles literature). This preference specification is compatible with a balanced growth path and is also consistent with the high real exchange rate volatility that is observed in the data. A more elastic labor supply and a greater intertemporal elasticity of substitution in consumption generates more volatile real exchange rates. Hence, this preference specification provides more plausible implications for the short-run dynamics of several macroeconomic variables relative to the redux model and better matches some observed regularities. ${ }^{11}$

While the discussion in this subsection has focused on only two issues with regard to the specification of preferences (the degree of substitutability of home and foreign goods in consumption and the separability of consumption and leisure in utility), the results of models with explicit microfoundations may depend crucially on the specification of the utility function in other ways. Relaxing the symmetry assumption in the utility function and allowing for nonseparable consumption and leisure, for example, would yield more plausible and more general utility functions. Of course, there are other related important issues and, in this respect, the closed economy literature can lend ideas on how to proceed; see, for example, the large and growing closed economy literature on habit formation and home production.

\section{Financial Markets Structure}

The redux model assumes that there is international trade only in a riskless real bond, and hence financial markets are not complete. Deviations from this financial markets structure have been examined in several papers. CKM (1998) compare, in the context of their PTM model, the effects of monetary shocks under complete markets and under a setting where trade occurs only in one noncontingent nominal bond denominated in the domestic currency. Their results show that the redux model is rather robust in this case. In fact, incompleteness of financial markets appears to imply small differences for the persistence of monetary shocks. ${ }^{12}$

A related study by Sutherland (1996) analyzes trading frictions (which essentially allow for a differential between domestic and foreign interest rates) in the context of an intertemporal general equilibrium model where financial markets are incomplete and the purchase of bonds involves convex adjustment costs. Goods markets are perfectly competitive and goods prices are subject to Calvo-type sluggish adjustment. Sutherland shows that barriers to financial integration have a larger impact on output the greater the degree of price inertia. With substantial price inertia, output adjusts slowly and more agents smooth their consumption pattern via international financial markets. Sutherland's simulations suggest that financial market integration increases the volatility of a number of variables when shocks originate from the money market but decreases the volatility of most variables when shocks originate from real demand or supply; these results also hold in the generalization of Sutherland's model by Senay (1998). For example, a positive domestic monetary shock induces a domestic interest rate decline and, therefore, a negative interest rate differential with the foreign country. In turn, the negative interest rate differential produces a smaller exchange rate depreciation and a larger jump in relative domestic consumption. This implies that domestic output rises less in this model than in the baseline redux model.

OR (1995) defend their assumptions regarding the financial markets structure of the redux model stating that it would seem incoherent to analyze imperfections or rigidities in goods markets, while at the same time assuming that international capital markets are complete. Indeed, one may argue that, if there were complete international risk sharing, it is unclear how price or wage rigidities could exist. Nevertheless, the assumption of full international capital integration is very controversial. While many economists would agree that the degree of financial integration has increased over

\footnotetext{
11 A further modification of the redux model considered by researchers involves the introduction of nontradables in the analysis, which typically implies an increase in the size of the initial exchange rate response to a monetary shock; see, for example, Ghironi (2000b), Hau (2000), and Warnock (1999).

12 Note, however, that none of the models discussed in this paper have complete markets in the Arrow-Debreu sense, with the possible exception of CKM (1998).
} 
time (at least across major industrialized countries), it is perhaps fair to say that there are frictions in financial markets (see Obstfeld, 1995). Given the controversies over what may constitute a realistic financial markets structure, the analysis of the impact of barriers to financial integration remains an avenue of research in its own right.

\section{The Role of Capital}

The literature has largely neglected the role of capital in new open economy models. For example, competitive models with capital can deliver effects of supply shocks similar to those typically found in monopolistically competitive models with endogenous utilization of capital (see, for example, Finn, 2000). ${ }^{13}$ CKM $(1998,2000)$ also argue that capital (omitted in the redux model and most subsequent variants of it) may play an important role because monetary shocks can cause investment booms by reducing the short-term interest rate and hence generate a current account deficit (rather than a surplus, as in the redux model). Explicitly allowing for capital in new open economy models is an important immediate avenue for future research.

\section{STOCHASTIC NEW OPEN ECONOMY MACROECONOMICS}

Recently, the certainty equivalence assumption that characterizes much of the literature discussed above (including the redux model) has been relaxed. While certainty equivalence allows researchers to approximate exact equilibrium relationships, it "precludes a serious welfare analysis of changes that affect the variance of output" (Kimball, 1995, p. 1243). Following this line of reasoning, OR (1998) first extend the redux model and the work by Corsetti and Pesenti (2001) to a stochastic environment. More precisely, the innovation in OR (1998) involves moving away from the analysis of only unanticipated shocks. ${ }^{14}$

\section{Risk and Exchange Rates}

The OR (1998) model may be interpreted as a sticky-price monetary model in which risk has an impact on asset prices, short-term interest rates, the price-setting decisions of individual producers, expected output, and international trade flows. This approach allows OR to quantify the welfare tradeoff between alternative exchange rate regimes and to relate such tradeoff to a coun- try's size. Another important finding of this model is that exchange rate risk affects the level of the exchange rate. Not surprisingly, as discussed below, the model has important implications for the behavior of the forward premium and for the forward discount bias.

The setup of the OR (1998) model adds uncertainty to the redux model. Most results are standard and qualitatively identical to those of the redux model. However, one of the most original results of this approach is the equation describing the equilibrium exchange rate. To obtain the equilibrium exchange rate, OR (1998) assume that Home and Foreign have equal trend inflation rates (equal to the long-run nominal interest rates through the Fisher equation) and use conventional log-linearizations (in addition to the assumption that PPP holds) to obtain an equation of nominal exchange rate determination. This equation may be interpreted as a monetary-model-type equation where conventional macroeconomic fundamentals determine the exchange rate. Also, this exchange rate equation is the same as in the redux model, except for a time-varying risk premium term. Under the assumption of no bubbles, the solution of the model suggests that a level risk premium enters the exchange rate equation. In some sense, this model may explain the failure of conventional monetary models of exchange rate determination in terms of an omitted variable in the exchange rate equation, namely, exchange rate risk; a similar result was obtained by Hodrick (1989) in the context of a cash-in-advance flexibleprice exchange rate model. For example, less relative risk of investments in the Home currency induces a fall in the domestic nominal interest rate and an appreciation of the domestic currency, capturing the idea of a "safe haven" effect on the Home currency.

For reasonable interest rates, a rise in Home monetary variability induces both a fall in the

\footnotetext{
${ }^{13}$ Finn (2000) demonstrates that a theory of perfect competition, which views capital utilization as the avenue through which energy enters into the model economy, can explain the observed effects of energy price increases on economic activity, which Rotemberg and Woodford (1996) and several subsequent studies defined as inexplicable without a theory of imperfect competition.

${ }^{14}$ Note, however, that I am using the term stochastic loosely here. Even in approximated dynamics with certainty equivalence, models are stochastic. Evaluations of the first-order effects of second moments (noncertainty equivalence) recognize an aspect of stochastic models that is often neglected, but this does not by itself define a stochastic model.
} 
level of the exchange rate risk premium and a fall in the forward premium (the latter fall is shown to be much larger in magnitude). This result contradicts the conventional wisdom that financial markets attach a positive risk premium to the currency with higher monetary volatility. The intuition is explained by OR (1998) as follows:

[A] rise in Home monetary volatility may lead to a fall in the forward premium, even holding expected exchange rate changes constant. Why? If positive domestic monetary shocks lead to increases in global consumption, then domestic money can be a hedge, in real terms, against shocks to consumption. (The real value of Home money will tend to be unexpectedly high in states of nature where the marginal utility of consumption is high.) Furthermore-and this effect also operates in a flexible-price model-higher monetary variability raises the expectation of the future real value of money, other things equal. (p. 24)

This result provides a novel theoretical explanation of the forward premium puzzle. Not only should high interest rates not necessarily be associated with expected depreciation, but the opposite may also be true, especially for countries with similar trend inflation rates.

Nevertheless, the results produced by this model may well depend critically on the specification of the microfoundations and are, therefore, subject to the same caveats raised by the literature questioning the appropriateness of the redux specification. Thus, it is legitimate to wonder how adopting the other specifications (alternative specifications of utility, different nominal rigidities, etc.) described earlier would affect the results of the OR (1998) stochastic model. The next subsection discusses, for example, the changes induced by the introduction of PTM in this model.

\section{Related Studies}

The OR (1998) analysis described above is based on the following assumptions: (i) that producers set prices in their own currency, (ii) that the price paid by foreigners for home goods (and the price paid by domestic residents for foreign goods) varies instantaneously when the exchange rate changes, and (iii) that the LOOP holds. Devereux and Engel (1998) extend the OR (1998) analysis by assuming PTM and that producers set a price in the home currency for domestic residents and in the foreign currency for foreign residents. Hence, when the exchange rate fluctuates, the LOOP does not hold. The risk premium depends on the type of price-setting behavior of producers. Devereux and Engel compare the agent's welfare between fixed and flexible exchange rate arrangements and find that exchange rate systems matter not only for the variances of consumption, real balances, and leisure but also for their mean values once risk premia are incorporated into pricing decisions. Since PTM insulates consumption from exchange rate fluctuations, floating exchange rates are less costly under PTM than under producer currency pricing. Consequently, a flexible regime generally dominates a pegged regime. ${ }^{15}$

Engel (1999) makes four points in summarizing the evidence on the foreign exchange risk premium in this class of general equilibrium models. First, while the existence of a risk premium in flexible-price general equilibrium models depends on the correlation of exogenous monetary shocks and aggregate supply shocks, the risk premium arises endogenously in sticky-price models. Second, the distribution of aggregate supply shocks does not affect the foreign exchange risk premium in sticky-price models. Third, given that the risk premium depends on the prices faced by consumers, when the LOOP does not hold there is no unique foreign exchange risk premium since producers set prices in consumers' currencies. Fourth, standard stochastic dynamic general equilibrium models do not usually imply large risk premia.

The common denominator in these models is that the exchange rate risk premium is an important determinant of the equilibrium level of the exchange rate. It remains an open question whether one could build a sticky-price model capable of convincingly explaining the forward premium puzzle. Nevertheless, this seems a promising avenue for future research.

\section{NEW DIRECTIONS: THE SOURCE OF NOMINAL RIGIDITIES AND THE CHOICE BETWEEN LOCAL AND FOREIGN CURRENCY PRICING}

OR (2000a) may have again set new directions for stochastic open economy models of the class

\footnotetext{
${ }^{15}$ See also Bacchetta and van Wincoop (1998).
} 
discussed in this paper. They start by noting that the possibilities for modeling nominal rigidities are more numerous in a multicurrency international economy than in a single-money closed economy setting and that, in an international setting, it is natural to consider the possibility of segmentation between national markets. OR address the empirical issue of whether local currency pricing or foreign currency pricing is closer to reality. OR argue that, if imports are invoiced in the importing country's currency, unexpected currency depreciations should be associated with improvements (rather than deteriorations) in the terms of trade. They then show that this implication is inconsistent with the data. Indeed, their evidence suggests that aggregate data may favor a traditional framework in which exporters largely invoice in home currency and nominal exchange rate changes have significant short-run effects on international competitiveness and trade.

The main reservations of OR about the PTMlocal currency pricing framework employed by several papers in this literature are captured by the following observations. First, a large fraction of measured deviations from the LOOP results from nontradable components incorporated in consumer price indices for supposedly traded goods (for example, rents, distribution services, advertising, etc.); it is not clear whether the extreme market segmentation and pass-through assumptions of the PTM-local currency pricing approach are necessary to explain the close association between deviations from the LOOP and exchange rates. Second, price stickiness induced by wage stickiness is likely to be more important in determining persistent macroeconomic fluctuations since trade invoicing cannot generate sufficiently high persistence. (Invoicing largely applies to contracts of 90 days or less.) Third, the direct evidence on invoicing is largely inconsistent with the view that exporters set prices mainly in importers' currencies (see, for example, ECU Institute, 1995); the United States is, however, an exception. Fourth, international evidence on markups is consistent with the view that invoicing in exporters' currencies is the predominant practice (see, for example, Goldberg and Knetter, 1997).

OR (2000a) build their stochastic dynamic open economy model with nominal rigidities in the labor market (rationalized on the basis of the first two observations above) and foreign currency pricing (rationalized on the basis of the last two observations above). They consider a standard twocountry global economy where Home and Foreign produce an array of differentiated tradable goods (Home and Foreign have equal size). In addition, each country produces an array of differentiated nontraded goods. Workers set next period's domestic-currency nominal wages and then meet labor demand in the light of realized economic shocks. Prices of all goods are completely flexible.

OR provide equilibrium equations for preset wages and a closed-form solution for each endogenous variable in the model as well as solutions for variances and for utility. In particular, the solution for the exchange rate indicates that a relative Home money supply increase that occurs after nominal wages are set would cause an overshooting depreciation in the exchange rate. A fully anticipated change, however, causes a precisely equal movement in the wage differential and in the exchange rate.

In this setup, OR show welfare results on two fronts. First, they show that constrained-efficient monetary policy rules replicate the flexible-price equilibrium and feature a procyclical response to productivity shocks. ${ }^{16}$ For example, a positive productivity shock that would elicit greater labor supply and output under flexible wages optimally induces an expansionary Home monetary response when wages are set in advance. The same shock elicits a contractionary Foreign monetary response, but the net global monetary response is always positive. Also, optimal monetary policy allows the exchange rate to fluctuate in response to crosscountry differences in productivity shocks. This conclusion is similar to the result obtained by King and Wolman (1996) in a rational expectations model where monetary policy has real effects because imperfectly competitive firms are constrained to adjust prices only infrequently and to satisfy all demand at posted prices. In the KingWolman sticky-price model, it is optimal to set monetary policy so that the nominal interest rate is close to zero (that is, neutralizing the effect of the sticky prices), replicating in an imperfectly competitive model the result that Friedman found under perfect competition. Under a perfect infla-

\footnotetext{
16 These monetary policy rules are (i) constrained since they are derived by maximizing an average of Home and Foreign expected utilities subject to the optimal wage-setting behavior of workers and price-setting behavior of firms described in the model, and (ii) efficient since the market allocation cannot be altered without making one country worse off, given the constraints.
} 
tion target, the monetary authority makes the money supply evolve so that a model with sticky prices behaves much like one with flexible prices.

Second, OR calculate the expected utility for each of three alternative monetary regimes, namely, an optimal floating rate regime, world monetarism (under which two countries fix the exchange rate while also fixing an exchange rateweighted average of the two national money supplies), and an optimal fixed rate regime. The outcome is that the expected utility under an optimal floating-rate regime is highest. This result is intuitively obvious given that optimal monetary policy in this model involves allowing the exchange rate to fluctuate in response to cross-country differences in productivity shocks. Fixed-rate regimes would only be worthwhile if productivity shocks at home and abroad were perfectly correlated. ${ }^{17}$

The OR (2000a) model addresses several theoretical and policy questions, including welfare analysis under alternative nominal regimes. The assumption that nominal exchange rate movements shift world demand between countries in the short run, which plays a crucial role in the traditional MFD model, is shown to be consistent with the facts and can reasonably be used as a building block in stochastic open economy models. Needless to say, this approach warrants further generalizations and refinements. In particular, note that the current account is shut off in OR (2000a) to avoid the indeterminacy problem discussed earlier. However, shutting off the current account makes the model less plausible from an empirical point of view since it distorts the dynamics of the economy being modeled.

It is worth noting that the new open economy macroeconomics literature to date has (implicitly or explicitly) assumed that there are no costs of international trade. Nevertheless, the introduction of some sort of international trade costs (including, among others, transport costs, tariffs, and nontariff barriers) may be key in understanding how to improve empirical exchange rate models and in explaining several unresolved puzzles in international macroeconomics and finance. While the allowance of trade costs in open economy modeling is not a new idea and goes back at least to Samuelson (1954), OR (2000c) have recently stressed the role of trade costs in open economy macroeconomics. Indeed, OR (2000c) present something of a "unified theory" that helps elucidate what the profession may be missing when trying to explain several puzzling empirical findings using trade costs as the fundamental modeling feature, with sticky prices playing a distinctly secondary role. It is hoped that future research in new open economy macroeconomics follows the suggestion of OR (2000c) to make explicit allowance for non-zero international trade costs.

\section{CONCLUSIONS}

In this paper, I have selectively reviewed the recent literature on new open economy macroeconomics, which has been growing exponentially in the last five years or so. The increasing sophistication of stochastic open economy models allows rigorous welfare analysis and provides new explanations of several puzzles in international macroeconomics and finance. Whether this approach will become the new workhorse model for open economy macroeconomics, whether a preferred specification within this class of models will be reached, and whether this approach will provide insights on developing better-fitting empirical exchange rate models are open questions.

Although the theory in the spirit of new open economy macroeconomics is developing very rapidly, there is little effort at present to test the predictions of new open economy models. Theorists working in this area should specify exactly which empirical exchange-rate equations they would have empiricists estimate. If there is to be consensus in the profession on a particular model specification, this theoretical apparatus has to produce clear estimable equations. ${ }^{18}$

Agreeing on a particular new open economy model is hardly possible at this stage. This is the case not least because it requires agreeing on assumptions which are often difficult to test directly (such as the specification of the utility function) or because they concern issues on which economists have strong beliefs on which they have not often been willing to compromise (such as whether nominal rigidities originate from the goods market or the labor market or whether

\footnotetext{
17 Indeed, the results suggest that the difference between the expected utility under an optimal floating-rate regime and the expected utility under an optimal fixed-rate regime may not be too large if the variance of productivity shocks is very small or the elasticity of util ity with respect to effort is very large.

18 A first step toward new open economy macroeconometrics has been made, for example, by Ghironi (2000c). I am also currently investigating empirical exchange rate equations inspired by the new open economy macroeconomics literature.
} 
nominal rigidities exist at all). Achieving a new paradigm for open economy modeling is, however, a major challenge which lies ahead for the profession. While the profession shows some convergence toward a consensus approach in macroeconomic modeling (where the need for microfoundations, for example, seems widely accepted), it seems very unlikely that a consensus model will emerge in the foreseeable future.

\section{REFERENCES}

Andersen, Torben M. "Persistency in Sticky Price Models." European Economic Review, May 1998, 42(3-5), pp. 593603.

Bacchetta, Philippe and van Wincoop, Eric. "Does Exchange Rate Stability Increase Trade and Capital Flows?" Discussion Paper 1962, Centre for Economic Policy Research, September 1998.

Backus, David K.; Kehoe, Patrick J. and Kydland, Finn E. "International Real Business Cycles." Journal of Political Economy, August 1992, 100(4), pp. 745-75.

and "Dynamics of

the Trade Balance and the Terms of Trade: The J-Curve?" American Economic Review, March 1994, 84(1), pp. 84103. and . "International

Business Cycles: Theory and Evidence," in Thomas F. Cooley, ed., Frontiers of Business Cycle Research. Princeton: Princeton University Press, 1995.

Barro, Robert J. and Gordon, David B. "Rules, Discretion and Reputation in a Model of Monetary Policy." Journal of Monetary Economics, July 1983, 12(1), pp. 101-21.

Baxter, Marianne and Crucini, Mario. "Business Cycles and the Asset Structure of Foreign Trade.” International Economic Review, November 1995, 36(4), pp. 821-54.

Benigno, Gianluca. "Real Exchange Rate Persistence with Endogenous Monetary Policy.” Unpublished manuscript, University of California, Berkeley, 1999.

Benigno, Pierpaolo. "Optimal Monetary Policy in a Currency Area.” Unpublished manuscript, New York University, 2001.

Bergin, Paul R. and Feenstra, Robert C. "Pricing to Market, Staggered Contracts and Real Exchange Rate Persistence."
Working Paper No. 99/01, University of California, Davis, February 1999.

and "Staggered Price Setting, Translog Preferences, and Endogenous Persistence." Journal of Monetary Economics, June 2000, 45(3), pp. 657-80.

Betts, Caroline and Devereux, Michael B. "The Exchange Rate in a Model of Pricing-to-Market.” European Economic Review, April 1996, 40(3-5), pp. 1007-21. and “The International Monetary Transmission Mechanism: A Model of Real Exchange Rate Adjustment Under Pricing-to-Market." Unpublished manuscript, University of British Columbia, 1997.

and "The International Effects of Monetary and Fiscal Policy in a Two-Country Model." Unpublished manuscript, University of British Columbia, 1999.

and "International Monetary Policy Coordination and Competitive Depreciation: A ReEvaluation." Journal of Money, Credit and Banking, November 2000a, 32(4), pp. 722-45.

and "Exchange Rate Dynamics in a Model of Pricing-to-Market." Journal of International Economics, February 2000b, 50(1), pp. 215-44.

Blanchard, Olivier J. and Kiyotaki, Nobuhiro. "Monopolistic Competition and the Effects of Aggregate Demand." American Economic Review, September 1987, 77(4), pp. 647-66.

Calvo, Guillermo A. "Staggered Prices in a Utility-Maximizing Framework." Journal of Monetary Economics, September 1983, 12(3), pp. 383-98.

Chari, V.V.; Kehoe, Patrick J. and McGrattan, Ellen R. "Monetary Shocks and Real Exchange Rates in Sticky Price Models of International Business Cycles." Unpublished manuscript, Federal Reserve Bank of Minneapolis, 1998.

and "Sticky Price

Models of the Business Cycle: Can the Contract Multiplier Solve the Persistence Problem?" Econometrica, September 2000, 68(5), pp. 1151-79.

Corsetti, Giancarlo and Pesenti, Paolo. "Welfare and 
Macroeconomic Interdependence." Quarterly Journal of Economics, 2001 (forthcoming).

Devereux, Michael B. "Do Fixed Exchange Rates Inhibit Macroeconomic Adjustment?" Unpublished manuscript, University of British Columbia, 1999.

and Engel, Charles. "Fixed vs. Floating

Exchange Rates: How Price Setting Affects the Optimal Choice of Exchange-Rate Regime." Working Paper No. 6867, National Bureau of Economic Research, 1998.

Dixon, Huw and Rankin, Neil. "Imperfect Competition and Macroeconomics: A Survey." Oxford Economic Papers, April 1994, 46(2), pp. 171-99.

Dornbusch, Rudiger. "Expectations and Exchange Rate Dynamics." Journal of Political Economy, December 1976, 84(6), pp. 1161-76.

Doyle, Brian M. "Reputation and Currency Crises (or 'Countries of a Feather Devalue Together')." Unpublished manuscript, Board of Governors of the Federal Reserve System, 2000.

ECU Institute. International Currency Competition and the Future Role of the Single European Currency. London: Kluwer Law International, 1995.

Engel, Charles. "Real Exchange Rates and Relative Prices: An Empirical Investigation." Journal of Monetary Economics, August 1993, 32(1), pp. 35-50.

. "Accounting for U.S. Real Exchange Rate Changes." Journal of Political Economy, June 1999, 107(3), pp. 507-38.

and Rogers, John H. "How Wide Is the Border?" American Economic Review, December 1996, 86(5), pp. 1112-25.

Finn, Mary G. "Perfect Competition and the Effects of Energy Price Increases on Economic Activity." Journal of Money, Credit and Banking, August 2000, 32(3), pp. 40016.

Fleming, J. Marcus. "Domestic Financial Policies Under Fixed and Under Floating Exchange Rates." International Monetary Fund Staff Papers, November 1962, 9(3), pp. 369-80.

Ghironi, Fabio. “Macroeconomic Interdependence Under
Incomplete Markets.” Unpublished manuscript, Federal Reserve Bank of New York, 2000a.

"U.S.-Europe Economic Interdependence and Policy Transmission." Unpublished manuscript, Federal Reserve Bank of New York, 2000b.

"Towards New Open Economy Macroeconometrics.” Staff Report 100, Federal Reserve Bank of New York, 2000c.

and Rebucci, Alessandro. "Monetary Rules for Emerging Market Economies.” Unpublished manuscript, Federal Reserve Bank of New York and International Monetary Fund, 2000.

Goldberg, Pinelopi K. and Knetter, Michael M. "Goods Prices and Exchange Rates: What Have We Learned?" Journal of Economic Literature, September 1997, 35(3), pp. 1243-72.

Hau, Harald. "Exchange Rate Determination: The Role of Factor Price Rigidities and Nontradables." Journal of International Economics, April 2000, 50(2), pp. 421-47.

Hodrick, Robert J. "Risk, Uncertainty, and Exchange Rates.” Journal of Monetary Economics, May 1989, 23(3), pp. $433-59$.

Jeanne, Olivier. "Generating Real Persistent Effects of Monetary Shocks: How Much Nominal Rigidity Do We Really Need?" European Economic Review, June 1998, 42(6), pp. 1009-32.

Kimball, Miles S. "The Quantitative Analytics of the Basic Neomonetarist Model." Journal of Money, Credit and Banking, November 1995, 27(4), pp. 1241-77.

King, Robert G. and Wolman, Alexander L. "Inflation Targeting in a St. Louis Model of the 21 st Century." Federal Reserve Bank of St. Louis Review, May/June 1996, 78(3), pp. 83-107.

Knetter, Michael M. "International Comparisons of Priceto-Market Behavior.” American Economic Review, June 1993, 83(3), pp. 473-86.

Kollmann, Robert. "Incomplete Asset Markets and the Cross-Country Consumption Correlation Puzzle." Journal of Economic Dynamics and Control, May 1996, 20(5), pp. 945-61. 
"The Exchange Rate in a Dynamic-Optimizing Current Account Model with Nominal Rigidities: A Quantitative Investigation.” Working Paper WP/97/07, International Monetary Fund, January 1997.

Krugman, Paul R. "Pricing to Market When the Exchange Rate Changes," in Sven W. Arndt and J. David Richardson, eds., Real-Financial Linkages Among Open Economies. Cambridge, MA: MIT Press, 1987.

Lane, Philip R. "Inflation in Open Economies." Journal of International Economics, May 1997, 42(3-4), pp. 327-47.

"The New Open Economy Macroeconomics:

A Survey." Working Paper No. 2115, Centre for Economic Policy Research Discussion Paper, March 1999; forthcoming in Journal of International Economics.

"Money Shocks and the Current Account," in Guillermo Calvo, Rudiger Dorbusch, and Maurice Obstfeld, eds., Money, Capital Mobility, and Trade: Essays in Honor of Robert Mundell. Cambridge, MA: MIT Press, 2001.

Lucas, Robert E., Jr. "Interest Rates and Currency Prices in a Two-Country World." Journal of Monetary Economics, November 1982, 10(3), pp. 335-59.

Mundell, Robert A. "The Appropriate Use of Monetary and Fiscal Policy for Internal and External Stability." International Monetary Fund Staff Papers, March 1962, 9(1), pp. 70-79.

"Capital Mobility and Stabilization Policy Under Fixed and Flexible Exchange Rates." Canadian Journal of Economics and Political Science, November 1963, 29(4), pp. 475-85.

Obstfeld, Maurice. "International Capital Mobility in the 1990s," in Peter B. Kenen, ed., Understanding Interdependence: The Macroeconomics of the Open Economy. Princeton: Princeton University Press, 1995. and Rogoff, Kenneth. "Exchange Rate Dynamics Redux." Journal of Political Economy, June 1995, 103(3), pp. 624-60.

and Foundations of International Macroeconomics. Cambridge, MA: MIT Press, 1996. and "Risk and Exchange Rates."
Working Paper No. 6694, National Bureau of Economic Research, August 1998.

and "New Directions for Stochastic Open Economy Models.” Journal of International Economics, February 2000a, 50(1), pp. 117-53.

and "Do We Really Need a New International Monetary Compact?” Working Paper No. 7864, National Bureau of Economic Research, August 2000b.

and "The Six Major Puzzles in International Macroeconomics: Is There a Common Cause?" Working Paper No. W7777, National Bureau of Economic Research, July 2000c; in Ben Bernanke and Kenneth Rogoff, eds., National Bureau of Economic Research Macroeconomics Annual 2000. Cambridge, MA: National Bureau of Economic Research and MIT Press, 2001 (forthcoming).

Rotemberg, Julio J. and Woodford, Michael. "Imperfect Competition and the Effects of Energy Price Increases on Economic Activity." Journal of Money, Credit and Banking, November 1996, 28(4), pp. 550-77.

Samuelson, Paul. "The Transfer Problem and Transport Costs, II: Analysis of Effects of Trade Impediments." Economic Journal, June 1954, 64(254), pp. 264-89.

Sarno, Lucio. "Towards a New Paradigm in Open Economy Modeling: Where Do We Stand?" Unpublished manuscript, University of Warwick, 2000; available from Brian Doyle's New Open Economy Macroeconomics, $<$ http://www.geocities.com/brian_m_doyle/open.html > .

and Taylor, Mark P., eds. New Developments in Exchange Rate Economics, Volumes I-II, Critical Writings in Economics series. Northampton, MA: Edward Elgar, 2001a (forthcoming).

and Exchange Rate Economics. Cambridge, MA: Cambridge University Press, 2001b (forthcoming).

Senay, Ozge. "The Effects of Goods and Financial Market Integration on Macroeconomic Volatility." Manchester School, Supplement 1998, 66, pp. 39-61.

Stockman, Alan C. "A Theory of Exchange Rate Determination." Journal of Political Economy, August 1980, 88(4), pp. 673-98. 


\section{RE V I E W}

."The Equilibrium Approach to Exchange Rates." Federal Reserve Bank of Richmond Economic Review, March/April 1987, 73(2), pp. 12-30.

Sutherland, Alan. "Financial Market Integration and Macroeconomic Volatility." Scandinavian Journal of Economics, December 1996, 98(4), pp. 521-39.

Svensson, Lars E.O. and van Wijnbergen, Sweder. "Excess Capacity, Monopolistic Competition, and International Transmission of Monetary Disturbances." Economic Journal, September 1989, 99(397), pp. 785-805.

Taylor, John B. "Aggregate Dynamics and Staggered Contracts.” Journal of Political Economy, February 1980, 88(1), pp. 1-23.

Tille, Cédric. "Substitutability and Welfare." Unpublished manuscript, Federal Reserve Bank of New York, 1998a.

. "The Welfare Effects of Monetary Shocks

Under Pricing to Market: A General Framework."

Unpublished manuscript, Federal Reserve Bank of New York, 1998b.

Velasco, Andres. "Multiplicity and Cycles in a Real Model of the Open Economy." Unpublished manuscript, New York University, 1997.

Walsh, Carl E. Monetary Theory and Policy. Cambridge, MA: MIT Press, 1998.

Warnock, Francis E. "Idiosyncratic Tastes in a Two-Country Optimizing Model: Implications of a Standard Presumption.” Discussion Paper No. 631, International Finance Discussion Papers, Board of Governors of the Federal Reserve System, April 1999. 